Research Article

\title{
ONE STOP SERVICE PUBLIC INNOVATION IN THE NON TPI CLASS I IMMIGRATION OFFICE, SERANG CITY, INDONESIA
}

\author{
Kartika Shania Ningrum, Rethorika Berthanilla, Ahmad Sururi* \\ Departement of Public Administration, Serang Raya University, Serang Banten, 42111, Indonesia
}

Article history:

Submission 16 October 2020

Revised 11 November 2020

Accepted 24 December 2020

${ }^{*}$ Corresponding author:

E-mail:

sururiahmad20@gmail.com

\begin{abstract}
This study aims to determine the extent of implementation of the innovation one stop service at the Kantor Imigrasi Kelas I Non TPI Serang. This research uses descriptive method with qualitative approach. The technique of taking informants using snowball sampling technique combined with accidental sampling. This research was conducted at the Kantor Imigrasi Kelas I Serang from April 22, 2019 until August 27, 2019. The data were collected by observation, interview and documentation. Based on the results of this study concluded 1) innovation that run was good enough, 2) services provided when running the innovation was already good. While that is a contributing factor in the implementation of this innovation is 1) a queue at the immigration quota is not too much so as to sum up the work of immigration officers, 2) Immigration Office adequate facility for the community. Then the inhibiting factor is the lack of clear information dissemination to the public.
\end{abstract}

Keywords: Innovation, Service, One-stop service

\section{Introduction}

Public services are a basic right that must be obtained by all Indonesian people without exception and implemented by government agencies. Public services are not only limited to the output received by the community, but how are the ethics of government officials when carrying out their duties, for example in terms of speed, accuracy, friendliness, and several other things. The speed and accuracy in serving the community is often a problem that is quite often felt, such as waiting up to several days to get a product, the length of bureaucracy that must be taken, the lack of information provided. The current edition of the Oslo Manual identifies four types of innovation: 1) Product innovation: the introduction of a good or a service that is new or significantly improved in terms of its features and how to use. This includes significant improvements in technical specifications, components and materials, incorporated software, user-friendliness or other functional characteristics; 2) Process innovation: implementation of a significantly improved production or delivery mode. This includes significant changes in techniques, equipment and / or software; 3) Marketing Innovation: implementation of a new marketing method involving significant changes in product design or packaging, product placement, product promotion or

How to cite:

Ningrum K. S., Berthanilla, R., \& Sururi, A. (2020). One Stop Service Public Innovation in The Non TPI Class I Immigration Office, Serang City, Indonesia. Indonesian Journal of Social Science Research, 1 (1), 19 - 24. doi: 10.11594/ijssr.01.01.03 
pricing; 4) Organizational innovation: implementation of a new organizational method in the firm's business practices, workplace organization or external relations. (Matei \& Bujac, 2016)

The long bureaucracy that takes a long time makes people tend to be lazy to take care of matters related to the government bureaucracy so that mediators / brokers appear to simplify the service process needed. This condition is compounded by long queues that can even occur before the service office hours are opened to get the queue number (for walk-in applicants). the bureaucratic apparatus serving the public interest is still not aware of its function as public servants. the duties and responsibilities of the bureaucracy to provide services to the community undergo a change in function, namely the community serving the bureaucracy (Kumorotomo, 2015). Innovative policies in the service aspect are an important prerequisite for the creation of quality public services. This is at the same time to answer the demands of the dynamics of society which are increasingly developing and become a challenge for public sector organizations in making policy innovations that can provide satisfaction to the public (Sururi, 2019) and (Utomo, 2016) said that although innovation in Indonesia has developed rapidly, it is still being carried out relatively partially, piecemeal and stagnant. Partial because usually an innovation is not automatically connected to other innovations.

In the context of public services from the government to the community, people's satisfaction is fulfilled if what the government provides to them is what they expect. According to (Syafiie, 2003). So, if what they receive is that the manufacturing is carried out in a protracted manner, the costs incurred are quite high and not transparent, and then the quality of the permit is poor, unreadable, wrong date and name, or wrong location hence society is not satisfied.
Therefore, creative and innovative public services are a necessity as an effort to meet the needs of satisfying public services. that public service innovation is a breakthrough in the type of service, both original creative ideas / ideas and / or adaptations / modifications that provide benefits to the community, either directly or indirectly, as stipulated in the Regulation of the Minister of Administrative Reform and Bureaucratic Reform Number 30 of 2014 concerning Public Service Innovation Guidelines.

One of the public sector organizations that carry out public service functions in Serang City is the Class I Non TPI Serang Immigration Office which is located in Serang City and under the authority of the Directorate General of Immigration. And in an effort to improve the quality of public services and community satisfaction in providing service for passport applications, the Class I Non-TPI Immigration Office implements the One Stop Service (OSS) program or the Integrated Passport Service System (SPPT). This service itself was only implemented at the Class I Non TPI Serang Immigration Office in November 2017. The simplification of the long service procedure flow which previously had to come 3 (three) times to 2 (two) times and previously queued 4 times became 1 (once) in carrying out passport services.

Based on the results of the pre-research, the socialization of One Stop Service services carried out by the Class I Non TPI Serang Immigration Office was carried out through Car Free Day activities and dissemination of social media information. Besides socialization through banner and banner information (two languages). Even so, the number of walk-in applicant visits was still there, but not too many. The following is the report on the number of passport issuances at the Class I Non-TPI Serang Immigration Office as follows: 
Table 1. Statistic Report Per Passport Type Application for SPRI Documents by Passport Type Period 01 January - 31 December 2018

\begin{tabular}{lccc}
\hline & $\begin{array}{c}24 \text { h per- } \\
\text { orangan }\end{array}$ & $\begin{array}{c}48 \text { h per- } \\
\text { orangan }\end{array}$ & Total \\
\hline New - Ordinary Passport & 359 & 19323 & 19682 \\
\hline New - TKI passport & 809 & 6 & 815 \\
\hline Reimbursement - Expired & 305 & 8962 & 9267 \\
\hline Replacement- Full page & 10 & 149 & 159 \\
\hline Replacement - Missing & 1 & 168 & 169 \\
\hline Replacement - Damage is still in effect due & 2 & 41 & 43 \\
\hline Replacement - Broken Drowning / Disaster & 0 & 6 & 6 \\
\hline replacement ex Holder & 42 & 254 & 296 \\
\hline Lost Replacement Expire & 1 & 161 & 162 \\
\hline Replacement for Damaged Valid & 0 & 4 & 4 \\
\hline \multicolumn{1}{c}{ Total } & 1529 & 29074 & 30603 \\
\hline
\end{tabular}

Based on the Table 1, it can be explained that the number of passport issuances in 2018 reached 30,603. This number is relatively high, so the idea of public service innovation is one of the policy priorities. That innovation in public sector organizations is assumed to be an effort to get to a better state; the more innovative a government administration is, the greater the benefits - an added value - for society (Kimberly, 1981) in (Holidin et al., 2016) while (Sururi, 2016) argued that innovation in the context of public policy as a in principle and substantively it will provide reinforcement in responding and solving problems in society.

\section{Innovation and Public Services}

This breakthrough is motivated by the high number of passport applicants who come to the Immigration Office every day, the practice of brokering, long queues at the service office, professionalism of Immigration officers, and low certainty of service. Innovation in its implementation has attributes in it. According to (Rogers, 1995) the attributes of innovation include 1) Relative Advantage or relative advantage; 2) Compability or suitability; 3 ) Complexity or complexity; 4) Triability or trialability; 5) Observability or ease of observation. According to Fitzsimmons in (Sinambela, 2016) argues that there are five indicators of public services, namely reliability which is marked by the provision of appropriate and correct services; tangibles which are characterized by the adequate provision of human resources and other resources; responsiveness which is characterized by wanting to serve consumers quickly; assurance, which is characterized by the level of attention to ethics and morals in providing services; and empathy, which is indicated by the level of willingness to know the wants and needs of consumers. The purpose of this study was to analyze how the implementation of a one-stop service innovation at the Class I Non-TPI Serang Immigration Office. It seems possible to say that the term "public services" is typically applied to -activities of government in the public domain, such as policing and public health; activities done for the benefit of the public, like public service broadcasting or rubbish collection; and social services', like medical care, housing, education and social care (Spicker, 2009).

\section{Method}

The method used in this research is descriptive method with a qualitative approach. Descriptive research method is research that aims to describe or explain something as it is. This paradigm is characterized as research with the character of deteminism, reductionism, empirical observation and measurement, and accompanied by theory verification (Creswell, 1994). That qualitative research or naturalistic inquiry is a method of research that is intended to understand actuality, social reality, and existing human perceptions (Guba \& 
Lincoln, 1989). The location of this research was carried out at the Class I Non TPI Serang Immigration Office. With the technique of determining informants using the snowball sampling technique, combined and combined using the Accidental Sampling technique. While the data collection techniques carried out in this study are primary sources (interviews, and observations), and secondary sources (library research and documentation).

\section{Results and Discussion}

To find out to what extent the innovation of the one stop service public service at the Class I Non-TPI Serang Immigration Office, the researcher used the innovation attribute analysis tool according to (Rogers, 1995), namely the following research results:

1) Relative Advantage, shows that in implementing one stop service innovation has been running quite well. Judging from the advantages or added value for immigration officers after the innovation of one stop service is caused by the queue quota that is not too much, so that the service for these innovations does not take a long time; 2) Conformity, passport applicants generally do not find it difficult to adapt to this innovation. This is because the innovation of one stop service itself is only a reduction in procedures. As a result, the community or passport applicants do not experience problems or difficulties while adapting to this innovation; 3) Complexity, for the community itself, it is easier to understand the process of making passports and does not cause significant difficulties during the passport application process at the Class I Immigration Office Non TPI Serang; 4) Possibility to Try, some passport applicants admit that the current quality of innovation is much better than before, but what really stands out in innovation is the queue system alone; 5) Ease of observation, based on what the researchers found in the field by showing that the results given after this innovation were only on the queue side. Meanwhile, the overall results after implementing this one stop service innovation are still the same as before the implementation of this innovation.

In addition, service while carrying out these innovations is the focus of this study, research- ers use service indicators proposed by Fitzsimmons in Budiman in (Sinambela, 2016) argues that there are five indicators of public service, namely 1) reliability, 2) tangibles, 3) responsiveness, 4) assurance and 5) empathy. Here are the results:

1) Reliability, immigration officers are sufficient to provide appropriate and correct services to the community by notifying the information needed at that time; 2) Tangibles, the provision of resources and other resources at the Class I Non-TPI Serang Immigration Office has been going well; 3) Responsiveness, the lack of responsiveness in the field of services that handles socialization and dissemination of information which results in difficulty for passport applicants to find out the important information they need; 4) Assurance, immigration officers pay enough attention, especially to passport applicants who have just arrived for the first time or for passport applicants who will change their passports; 5) Empathy, immigration office officers are quite nimble, in the sense that they are responsive to applicants who look confused at the Immigration Office and ask if there are things that can be helped. In addition, the passport applicant also added that the presence of a responsive officer was very helpful in the passport process.

\section{Conclusions}

In implementing the one stop service innovation at the Class I Non TPI Serang Immigration Office, it has been running quite well. This can be seen from the public opinion in the process of applying for a passport which is classified as good. However, in its implementation, several obstacles are still found, such as the lack of clear information dissemination regarding the process of applying for a new or changing passport. So that people still find people who come to the Immigration Office directly just to ask questions regarding the required documents. Based on the above conclusions, the researchers suggest: 1) To Immigration Officers to be more responsive both when on duty or through any form of media. And to continue to socialize about this innovation so that all people can feel the benefits; 2) The researcher suggests expanding the network or channel for disseminating information through the official 
website, social media and other forms of media that can be seen by all people without the need to visit the Class I Non-TPI Serang Immigration Office; 3) To continue to optimize the speed, accuracy and responsiveness of officers to passport services at the Class I Non-TPI Serang Immigration Office; 4) Do not forget to provide education in the form of procedures or procedures for applying for a new passport or changing passports which are packaged by making video tutorials that can be shown in the service waiting room.

\section{Reference}

Creswell, J. W. (1994). Research Design: Qualitative and Quantitative Approaches. Thousand Oaks: SAGE Publications.

Guba, Y., \& Lincoln, E. (1989). Fourth Generation Evaluation. London. SAGE Publications Inc.

Holidin, I., Hariyanti, D., \& Sunarti, Eka, S. (2016) Reformasi Birokrasi dalam Transisi. Jakarta: KENCANA.

Kumorotomo, W. (2015). Etika Adminsitrasi Negara. Jakarta: PT Raja Grafindo Persada.

Matei, A., \& Bujac, R. (2016). Innovation and Public Reform. Procedia Economics and Finance, 39(November 2015), 761-768. https://doi.org/10.1016/s22125671(16)30278-7

Regulation of the Minister of Administrative Reform and Bureaucratic Reform Number 30 of 2014 concerning Public Service Innovation Guidelines.

Rogers, E. M. (1995). "Diffusion of Innovations". In New York: The Free Press.

Sinambela. (2016). Reformasi Pelayanan Publik (Teori, Kebijakan , dan Implementasi). Jakarta: PT Bumi Aksara.

Spicker, P. (2009). The Nature of a Public Service. International Journal of Public Administration, 32(11), 970-991. https://doi.org/10.1080/01900690903050927

Sururi, A. (2016). Inovasi Kebijakan Publik (Tinjauan Konseptual dan Empiris). Sawala Jurnal Administrasi Negara, 4 (September-Desember 2016), 1-14.

Sururi, A. (2019). Inovasi Kebijakan Organisasi Sektor Publik menuju Terwujudnya Good Public Policy Governance. Good Governance LAN Jakarta, 15 (1). https://stialan.ac.id/jurnal/index.php/gg/articl e/view/96

Syafiie, I. (2003). Sistem Administrasi Negara Republik Indonesia (SANRI). Jakarta: PT Bumi Aksara.

Utomo, T. W. (2016). Inovasi sebagai keniscayaan baru dalam Ilmu dan Praktek Administrasi Publik di Indonesia,. Laskar Inovasi Deputi Inovasi Administrasi Negara, Jakarta. 